\title{
INTEREST OBLIGATIONS IN REAL ESTATE TRANSACTIONS A RESEARCHER'S GUIDE*
}

\author{
H.J. LYNDON IRWIN**
}

\begin{abstract}
As in other areas of the law which are sensitive to economic change, the jurisprudence relating to the exaction of interest under land mortgages and agreements for the purchase and sale of land has undergone significant refinement in recent years. This paper seeks to provide a brief summary of the present law, and to identify some of the unresolved issues. No attempt has been made to analyze the authorities critically. Primarily it is hoped that the compilation of cases will provide a useful reference source for further research.***
\end{abstract}

\section{LAND MORTGAGES}

\section{A. INTEREST BEFORE MATURITY}

\section{Express or Implied Contract}

The mortgagor's obligation to pay interest before maturity of principal arises as a matter of contract, express or implied. Generally, the mortgagor is obliged to pay interest to the mortgagee on the principal of the loan at whatever rate is specified in the mortgage agreement.

The Interest Act ${ }^{1}$ does not purport to limit the rate of interest charged on moneys secured by mortgages of real estate. Rather, its objective is to ensure disclosure in the mortgage contract of the amount of the principal and the rate of interest payable. ${ }^{2}$ However, a limit may be placed upon the rate of interest recoverable by other legislation, such as The Unconscionable Transactions $\mathrm{Act}^{3}$ and s.305.1 of the Criminal Code ${ }^{4}$ (a "criminal rate" being an annual rate exceeding $60 \%$ on the credit advanced). While it is beyond the scope of this paper to consider in detail the provisions of the Unconscionable Transactions Act, there are several useful cases in this area. ${ }^{5}$

Prior to the enactment of unconscionable transactions legislation, a provision for payment of a bonus or an excessive rate of interest by a

* This article is based on a paper delivered at the 1983 Mid-Winter Meeting of the Alberta Branch of the Canadian Bar Association. The law is stated on the basis of authorities available as of January $15,1983$.

** With the firm of Frohlich, Irwin \& Rand of Edmonton.

*** Many of the foregoing topics are treated in Falconbridge on Mortgages ${ }^{125}$ and Di Castri's The Law of Vendor and Purchaser, ${ }^{128}$ both of which were invaluable touchstones in the preparation of this summary. Other useful references were Canadian Mortgage Practice Reporter, ${ }^{127}$ Lamont's Real Estate Conveyancing ${ }^{128}$ and McCaul's Remedies of Vendors and Purchasers. ${ }^{129}$

1. R.S.C. 1970 , c. 1-18.

2. See Goodhue v. Widdifield (1861) 8 Gr. 531; Sparling v. Cunningham (1906) 4 W.L.R. 336 (Y.T. Chambers); Can. Mtge. Invt. v. Cameron(1917) 55 S.C.R. 409; Standard Reliancev. Stubbs (1917) 55 S.C.R. 422; London Loan \& Savings Co. v. Meagher [1930] S.C.R. 378; Asconi Building Corp. v. Vocisano [1947] S.C.R. 358.

3. R.S.A. 1980 , c. U-2.

4. R.S.C. 1970 , c. C-34 as am.

5. Unrau v. Modern Finance (1970) 74 W.W.R. 662 (B.C.C.A.); Krocker v. Midtown Mtge. (1975) 52 D.L.R. (3d) 286 (Alta. S.C.T.D.); Schloss v. Koehler (1978) 4 Alta. L.R. (2d) 85 (Alta. S.C.T.D.); Kozina v. Trans-Alta. Mtge. (1979) 24 A.R. 405 (Alta. Q.B.). 
subservient borrower might have been set aside in equity as unconscionable. ${ }^{6}$ In a proper case, a plea of non est factum might also be a basis of avoiding payment of a bonus or an excessive rate of interest.?

The constitutional validity of the Unconscionable Transactions Relief Act (Ontario) ${ }^{8}$ was challenged in A.G. Ontario v. Barfried Enterprises, but was upheld because its primary purpose is to enlarge the equitable jurisdiction of the Court. ${ }^{9}$

Mortgage interest provisions which contravene s. 305.1 of the Criminal Code are severable from the agreement, and the obligation to repay the principal sum advanced will be enforced. ${ }^{10}$

\section{Statutory Rate}

If the mortgage does not expressly provide for payment of interest before maturity, and if the mortgage is not intended to be payable "without interest", it is doubtful whether there is an implied contract to pay interest from the date of advance of the principal sum at the statutory rate of five per cent per annum."

\section{B. INTEREST AFTER MATURITY}

\section{Express Contract}

After maturity, interest may be recovered at the rate stipulated in the mortgage only if the mortgage expressly so provides. In the absence of such agreement, interest can be recovered after maturity only as damages. Examples of cases in which the mortgage adequately provided for the payment of interest after maturity are Imperial Trusts v. New York Security ${ }^{12}$ and Pringle v. Hutson.$^{13}$ It is not enough to specify in the mortgage that the principal will bear interest "until paid". Instead, according to St. John v. Rykert ${ }^{14}$ and Peoples Loan v. Grant , ${ }^{15}$ it is necessary to state that interest will be payable "as well after as before maturity" or otherwise indicate that intention unequivocally.

\section{Interest as Damages}

The St. John and Peoples Loan cases limited the rate of interest (absent agreement) after default as damages to the statutory rate prescribed by section 3 of the Interest Act (then six per cent). Section 3 now provides that whenever interest is payable by law, and no rate is fixed by law, the

\footnotetext{
6. See Stephen Investments v. LeBlanc (1963) 41 W.W.R. 422 (Alta. S.C.).

7. Longleyv. Barbrick (1962) 36 D.L.R. (2d) 672 (N.S.S.C.).

8. R.S.O. 1980 , c. 514 .

9. See (1964) 42 D.L.R. (2d) 137 (S.C.C.).

10. See Mira Design v. Seascape Holdings [1982] 1 W.W.R. 744, [1982] 4 W.W.R. 99; and annotation (1982) 22 R.P.R. 193.

11. Consider Interest Act R.S.C. 1970, c. I-18, s. 3; Clyde v. Clyde (1945) O.W.N. 241; Peterson v. Bitzer [1922] I W.W.R. 141; Reid v. Wilson (1881) 9 P.R. 166 (Ont.); McDermott v. Keenan (1887) 14 O.R. 687.

12. (1905) 10 O.L.R. 289 (Divisional ct.).

13. (1909) 19 O.L.R. 652 (Ont. C.A.).

14. (1884) 10 S.C.R. 278.

15. (1890) 18 S.C.R. 262; See also Freehold Loan v. McLean(1891) 8 Man. R. 116.
} 
rate payable is five per cent per annum. Those cases may be taken to have overruled McDonald v. Elliott ${ }^{16}$ and Muttlebury v. Stephens, ${ }^{17}$ which had held that the rate of interest applicable after default is to be the ordinary value of money during the period of default, based upon all of the surrounding circumstances including the "before maturity" rate stated in the mortgage.

Under section 15 of the Judicature Act, ${ }^{18}$ the court may allow interest as damages on a just debt improperly withheld. As Prince Albert Pulp Co. v. Foundation Co. of Canada suggests, if this provision applies to mortgages in default, the Peoples Loan case may no longer restrict the interest rate after maturity to five per cent per annum. ${ }^{19}$ In the Prince Albert case, the rate fixed by the Court was the rate fixed "by law"; hence, section 3 of the Interest Act did not apply.

\section{Acceleration Clauses}

If the mortgage has not yet matured by effluxion of time, interest will be payable at the rate stated in the mortgage even if the mortgagee invokes an acceleration clause.$^{20}$ Needless to say, if a mortgage provides for the payment of interest on defaulted installments of interest only, interest will not be recoverable at the stated rate on the whole principal sum falling due under an acceleration clause. ${ }^{21}$

\section{Mistake of Law}

Monies erroneously paid after maturity at the "before maturity" rate are monies paid by mistake of law and therefore cannot be recovered unless there is an equitable basis to allow recovery. ${ }^{22}$

5. Interest after, but not before, Maturity

If a mortgage does not provide for the payment of interest before or after maturity, interest is still recoverable after maturity as damages. ${ }^{23}$ Quaere as to the effect of section 8 of the Interest Act. The enforceability of an express provision in a mortgage providing for the payment of interest after but not before maturity will be considered within, in the context of section 8 of the Interest Act.

\section{Merger: Section 13 of the Interest Act}

A significant issue is whether interest will run at the rate stated in the mortgage on a judgment obtained on the covenant for payment contained in the mortgage, or whether the taking of judgment on the covenant

16. (1886) 12 O.R. 98.

17. (1886) 13 O.R. 29 (Ch. Div.).

18. R.S.A. 1980 , c. J-1.

19. [1976] 4 W.W.R. 586 (S.C.C.).

20. See Muttleburyv. Stephens, supra n. 17; and Eastern Trust Co. v. Cushing Sulphite (1906) 3 N.B. Eq. 392.

21. Biggsv. Freehold Loan Co. (1900) 31 S.C.R. 136.

22. See Stewart v. Ferguson (1899) 31 O.R. 112; McKenzie v. McLeod (1909) 39 N.B.R. 230 (N.B.C.A.); B.C. Land Ltd. v. Robinson(1923) 3 W.W.R. 113 (B.C.C.A.).

23. See McDonnell v. West (1868) 14 Gr. 492; Reid v. Wilson supra n. 11; Clyde v. Clyde (1945) 2 D.L.R. 205 (Ont. High C.). 
for payment operates as a merger of the interest provisions of the mortgage so as to limit the rate of interest on the judgment to five per cent per annum under section 13 of the Interest Act. The British Columbia Supreme Court has held recently that a mortgage containing a provision that any judgment on the covenant should not operate as a merger of the covenant to pay interest at the rate specified in the mortgage, and further, that any judgment on the covenant should provide for interest on the judgment at the mortgage rate, entitled the mortgagee to a personal judgment which bore interest after entry at the mortgage rate instead of the statutory rate. ${ }^{24}$ The Manitoba Queen's Bench similarly so held in Chin Si-Thoo v. Berry , ${ }^{25}$ as did Master Funduk of the Alberta Queen's Bench in Spenrath Const. v. 206763 HIdgs. ${ }^{26}$ In the absence of express non-merger provisions in the agreement, the covenant for payment of interest merges in the judgment on the covenant for payment. ${ }^{27}$

That is not to say, however, in the latter case, that the mortgagee must ultimately discharge his mortgage after taking judgment on the personal covenant if interest is paid on the judgment debt at five per cent per annum only, because the mortgagee is still entitled to retain his mortgage security, as such, until the principal and interest at the rate fixed in the mortgage are paid. ${ }^{28}$

In the Chin Si-Thoo and Spenrath cases, it was held that the parties can contract out of section 13 of the Interest Act. Contrary authorities, however, are Dunn v. Malone ${ }^{29}$ and Edelweiss Credit Union v. Boehm. ${ }^{30}$ The Alberta Court of Queen's Bench, in Bank of Nova Scotia v. U.P.C. HIdgs. Ltd. , ${ }^{31}$ assumed without deciding that the parties can contract out of section 13. The Alberta Court of Appeal made a similar assumption, without deciding the issue, in Zero Stores v. K.A.H. Invt. Ltd. ${ }^{32}$

The issue may now have been resolved at the appeal court level by Norfolk Trust v. Wolcoski. ${ }^{33}$ In that case, the British Columbia Court of Appeal held that section 13 applies to limit the interest rate to five per cent on a judgment on the covenant for payment contained in a mortgage. The precatory words of section 2 of the Interest Act, "Except as otherwise provided by this Act", were decisive. No rate higher than five

24. Heller-Natofin (Western) Ltd. v. Carlton Developments Ltd. (1979) 11 R.P.R. 296 (B.C.S.C.). See also Coronation Credit v. Industrial Mortgage (1967) 64 D.L.R. (2d) 752 (B.C.S.C.).

25. (1978) 2 W.W.R. 641 (Man. Q.B.).

26. (1981) 32 A.R. 216 (Q.B.). An appeal to a justice of the Court of Queen's Bench was dismissed. See also Maple Credit v. Xomox Invts. Ltd. (1982) 21 Alta. L.R. (2d) 289 (Q.B.).

27. Re Sneyd (1883) 25 Ch.D. 338 (C.A.).

28. See Popple v. Sylvester (1882) 22 Ch.D. 98; Economic Life Assurance Society v. Usborne (1902) A.C. 147 (H.L.); Martens v. First National Mige. Co. (1982) 24 R.P.R. 260 (B.C.S.C.).

29. (1903) 6 O.L.R. 484 (Div. Ct.).

30. (1978) 6 R.P.R. 349 (B.C.S.C.).

31. (1979) 25 A.R. 117 (Q.B.).

32. (1982) Alta. D. 969-04.

33. (1982) 6 W.W.R. 189 (B.C.C.A.). 
per cent could be stipulated because section 2 makes section 13 applicable to personal judgments and so limits contractual freedom.

An Order Nisi in a foreclosure action has been held to be a judgment, ${ }^{34}$ but it probably is too late now to argue that section 13 of the Interest Act supercedes the interest provisions of the mortgage during the period of redemption fixed by the Order Nisi. It is settled by Economic Life Assur. Soc. v. Usborne ${ }^{35}$ that interest at the contractual rate is payable during the continuance of the mortgage security, and the security clearly continues during the period of redemption provided for in the Order Nisi.

A direction for payment of interest as a condition of granting a stay of proceedings is not affected by section $13 .{ }^{36}$

\section{ADVANCE OF FUNDS AND \\ COMMENCEMENT OF INTEREST}

\section{Interest Payable from Time of Advance}

Generally, interest is payable only from the time the principal sum is advanced and not from the date of making of the mortgage. However, the parties may expressly agree that interest will run from the date of the mortgage and interest will be payable from that date even if the advance is made later ${ }^{37}$ Even so, interest may not be recoverable from the date of the mortgage if the advance of funds is unreasonably delayed by the mortgagee. ${ }^{38}$

According to Orme v. Grant, ${ }^{39}$ the disbursement of funds to the solicitor for the mortgagee does not constitute an advance to the mortgagor. The mortgagee may, however, charge interest on unadvanced monies if he can show that monies have been set aside to pay-off prior encumbrances. ${ }^{40}$ On the other hand, failure to pay-off the encumbrances will result in interest being charged to the mortgagee on funds retained. ${ }^{41}$

To the extent that the amount of the mortgage exceeds the amount advanced under the mortgage, the mortgage will constitute a cloud on title. ${ }^{42}$ The mortgage would not constitute a cloud, however, if the unadvanced portion represented an agreed bonus. ${ }^{43}$

The onus of proving no advance is upon the person asserting it. ${ }^{44}$

34. See Trinity College v. Hill (1884) 8 O.R. 286 (Ch. Div.); Kolacz v. Munzell (1971) 5 W.W.R. 757 (Alta. S.C.).

35. Supran. 28.

36. See Rockwood Enterprises Ltd. v. Grain Insurance \& Guarantee Co. (1980) 4 W.W.R. 319 (Man. C.A.).

37. Edmonds v. Hamilton Provident \& Loan Soc. (1891) 18 O.A.R. 347 (C.A.).

38. Grossv. Galbraith (1932) 41 O.W.N. 397.

39. (1924) 26 O.W.N. 93.

40. Manleyv. London Loan Co. (1896) 26 S.C.R. 443; affg. 23 O.A.R. 139 (C.A.).

41. See Synod of Torontov. DeBlaquiere (1880) Cass. S.C. 539; affg. $27 \mathrm{Gr} .536$.

42. See Land Titles Act, R.S.A. 1980, c. L-5, s. 106.1; Calvert v. Burnham (1881) 6 O.A.R. 620.

43. Supran. 37.

44. Bennerv. Benner (1928) 3 D.L.R. 495 (Ont. S.C. App. Div.). 


\section{2. "Vendor take-back" Mortgages}

Quaere as to when the principal is advanced under a mortgage taken back by a vendor of land in partial payment of the purchase price. Is the principal advanced at the time of closing, at the time of making the mortgage or at the time of registration of the mortgage?

\section{3. "Wrap-around" or "Blanket" Mortgages}

Rigorous adherence to the principle that interest is payable only upon funds actually advanced has effectively scuttled the device of the "wraparound" or "blanket mortgage", according to Wagner v. Argosy Investments. ${ }^{45}$ Surely, in the absence of fraud or oppression, the concept of the wrap-around mortgage could be sustained on the basis of sanctity of contract, just as the courts have permitted the enforcement of bonus mortgages notwithstanding the earlier doctrine of equity that a mortgagee should not obtain an advantage by his security beyond his principal, interest and costs. ${ }^{46}$ In any case, the result in the Wagner case can readily be circumvented by structuring the transaction as an agreement for sale, (i.e. a deferred installment purchase contract) instead of a "blanket" mortgage.

\section{THE INTEREST ACT}

1. Section 6 of the Interest Act

\section{(a.) General}

By section 6 of the Interest Act, a mortgage which falls within one of the categories referred to in the section must contain a statement showing the amount of the principal money and the rate of interest chargeable thereon, calculated yearly or half-yearly, not in advance. The section provides for three governed categories of mortgage:

(a) a mortgage which is made payable on the sinking fund plan;

(b) a mortgage which is made payable on any plan under which the payments of principal money and interest are blended; and

(c) a mortgage which is made payable on any plan that involves an allowance of interest on stipulated repayments.

If a mortgage falling within any of the three categories does not contain the required statement with respect to principal and interest, no interest whatever is chargeable, payable or recoverable under the mortgage. Consequently, section 6 is constantly in the mind of the mortgage conveyancer and has been a fruitful source of litigation.

\section{(b.) Sinking Fund Plan}

The Interest Act does not define what is meant by a "sinking fund plan". An example of such a mortgage might be found in the case of Colonial Investment Co. v. Borland. ${ }^{47}$ The mortgage in that case provided for the payment of the principal sum of $\$ 600.00$ with interest at twelve per cent per annum on the 1st day of July, 1917, with the proviso,

45. (1979) 7 R.P.R. 305 (Ont. Dist. Ct.).

46. Supran. 37.

47. [1912] 2 W.W.R. 960 (Alta. C.A.). 
however, that the mortgage would be taken as paid in full if the mortgagor paid 120 monthly payments of $\$ 3.60$ each plus a stipulated fine for each month during which any installments should be unpaid plus the further sum of $40 \mathbb{4}$ per month for each $\$ 100.00$ advanced, on the first day of each month for 120 months, as a premium for the advance. The Alberta Court of Appeal held that this mortgage contravened section 6, without specifying the section 6 category within which the mortgage fell.

\section{(c.) Blended Payments}

The word "blended" has been interpreted to mean "mixed so as to be inseparable and indistinguishable". The Supreme Court of Canada has held that an installment which is by the mortgage to be applied firstly in payment of interest and secondly in reduction of principal is not a "blended" payment. ${ }^{48}$

On the other hand, if the mortgage does not stipulate that the installment is to be so applied, the installment is a "blended" payment. ${ }^{49}$ Payments are also not blended under a mortgage which calls for quarterly installments of principal in a fixed amount and the balance of principal in one year, with interest quarterly at a specified rate. ${ }^{50}$

In Cummings v. Silverwood, ${ }^{51}$ a mortgage which provided for a payment of $\$ 12,000.00$ without interest on a specified date and, in default, payment one month thereafter of $\$ 13,000.00$, with interest at six per cent on $\$ 13,000.00$ from the last named date, was held not to be a blended payment mortgage. Although the mortgagee had advanced $\$ 10,000.00$ only on the mortgage, the Court held that the mere addition of interest to principal was not a blending because there was no concealment of the amount to be paid for interest, and because the mortgagor understood perfectly how much he had to pay for the use of the $\$ 10,000.00$.

A statement in the mortgage that the principal sum is " $X$ ' dollars", and the rate of interest chargeable is " $Y$ ' per cent per annum", is a sufficient statement to satisfy the requirements of section 6 . A yearly computation of interest not in advance will be implied from that statement. ${ }^{52}$

\section{(d.) Allowance of Interest on Stipulated Repayments}

An example of a mortgage providing for an allowance of interest on stipulated repayments may be found in Commonwealth Savings v.

48. Re Kilgoran Hotels Lid. [1968] S.C.R. 3.

49. Re McGoran (1973) 37 D.L.R. (3d) 481 (Ont. H.C.). For an example of a blended payment mortgage, see Obee v. Laffey [1954] O.W.N. 510 (C.A.). Compare Mussens Can. Ltd. v. Maritime Rock Products Ltd. (1964) 49 D.L.R. (2d) 339 (N.S.S.C.). See also Mutual Finance v. Jost [1933] O.W.N. 17 (H.C.); Weinberg v. Elliott Hotel Ltd. [1960] O.W.N. 233 (C.A.). See Re Tilson (1976) 57 D.L.R. (3d) 491 (Ont. H.C.); Re Miglinn (1974) 50 D.L.R. (3d) 524 (Ont. C.A.). See also Ferland v. Sun Life Assurance Co. [1975] S.C.R. 266; Hudolin v. Premier Trust Co. (1977) 80 D.L.R. (3d) 414 (Ont. C.A.).

50. Bowman v. Denison (1930) 4 D.L.R. 671 (Ont. C.A.).

51. [1918] 3 W.W.R. 629 (K.B.T.D.).

52. See Canadian Mortgage Investment Co. v. Cameron [1917] 3 W.W.R. 521, 55 S.C.R. 409; Standard Reliance Mortgage Corp. v. Stubbs [1917] 3 W.W.R. 402, 55 S.C.R. 422; Standard Reliancev. Cowie [1917] 3 W.W.R. 238 (Sask. S.C.); Canadian Mortgage Investment Co. v. Baird [1916] 10 W.W.R. 1195 (Alta. S.C.T.D.); Re McGoran, supra n. 49. Compare with Poapst v. B.C. Permanent Loan Co. [1920] 2 W.W.R. 532 (Alta. S.C.T.D.). See also O'Hara v. Jeanson [1969] Que. S.C. 580. 
Triangle "C"' Cattle Co. ${ }^{53}$ In that case, a mortgage provided for payment of the principal sum of $\$ 150,000.00$ with interest at ten per cent, payable half-yearly. It further provided that the payments on account of the principal might be increased or reduced according to the cost of living index, and also that if all payments of interest were made promptly, the mortgagee would rebate three per cent interest, i.e. the difference between interest at ten per cent and seven per cent per annum. The mortgage was held to contain a sufficient statement to comply with section 6 . The case also decided that variable payments of principal are outside the ambit of the Interest Act. Also relevant in this area are the decisions in Colonial Investment \& Loan v. McKinley ${ }^{54}$ and Re Brown. ${ }^{55}$

A provision granting the mortgagor a prepayment privilege and the right to a return of interest paid in advance if the prepayment privilege is exercised is not a plan allowing interest on stipulated repayments. ${ }^{56}$

A recent decision of the Ontario High Court, ${ }^{57} \mathrm{Re}$ Weirdale Investments, has cast doubt on the enforceability of a claim for interest under any mortgage which provides for a reduction of interest if the payments of principal and interest are made on or before the due dates. That case held that such a provision, although not creating an unenforceable penalty in equity, ${ }^{58}$ has the effect of increasing the rate of interest on arrears of principal, and hence of fends section 8 of the Interest Act.

(e.) Bonus

Section 6 does not prevent the recovery of a bonus, notwithstanding that the bonus amounts to a prepayment of interest, and even if the mortgage provides for no payment of interest before default. ${ }^{59}$ Earlier Ontario authorities which had held that, in the case of a bonus mortgage, section 6 required that the mortgage contain a statement of the amount actually advanced, and the effective interest rate on that amount, appear to have been overruled by London Loan \& Savings Co. v. Meagher. ${ }^{60}$

In the Meagher case, the bonus was not payable by the terms of the mortgage itself, but by a collateral condition upon which the loan was made. In the Asconi ${ }^{61}$ case, Kerwin, J. held that there is nothing to prevent the parties to a loan transaction from agreeing, prior to the execu-

53. (1966) 55 W.W.R. 52 (B.C.C.A.).

54. [1912] 3 O.W.N. 949.

55. [1928] D.L.R. 1125 (Ont. S.C. App. Div.).

56. Ihnat v. Wetston (1978) 89 D.L.R. (3d) 595 (Ont. C.A.).

57. Re Weirdale Investments Ltd. (1981) 121 D.L.R. (3d) 151 (Ont. H.C.J.).

58. Wallingford v. Directors of Mutual Soc. (1880) 5 App. Cas. 685 (H.L.).

59. See London Loan \& Savings Co. v. Meagher, supra n. 2; Stephen Investments v. LeBlanc, supra n. 6; Re Desrochers (1956) O.W.N. 742 (Ont. H.C.J.); Mutual Finance Corp. v. Jost, supra n. 49; Asconi Building Corp. v. Vocisano, supra n. 2; Re Federal House Furnishing \& Outfitters (1954) 34 C.B.R. 19 (Ont. S.C.).

60. Supra n. 2. See also Singerv. Goldhar (1924) 2 D.L.R. 141 (Ont. S.C. App. Div.); Prousky v. Adelberg (1926) 4 D.L.R. 866 (Ont. S.C.); Lastarv. Poucher (1926) 2 D.L.R. 993 (Ont. S.C.); Ring v. Rosenfield (1926) 30 O.W.N. 76, 199 (Ont. S.C.); Thompson v. Wilson (1927) 32 O.W.N. 317 (Ont. S.C.); Re Brown, supra n. 55; Warner v. Doran (1931) 2 M.P.R. 574 (N.S.S.C.).

61. Supran. 2. 
tion of the mortgage, to the deduction or payment in advance of interest for the term of the mortgage, and then from providing by the mortgage document that there shall be no interest until default, and that the effect of such collateral agreement is that the prepaid interest ceases to be such and becomes part of the principal advanced. It is probably too late now to argue that a statement of the principal amount actually advanced and the effective interest rate thereon is necessary under section 6 if the bonus is provided for by the terms of the mortgage itself, and not by the terms of a prior or collateral agreement.

\title{
(f.) "By the Mortgage"
}

The phrase "by the mortgage" found in section 6 has been interpreted by both London Loan \& Savings Co. v. Meagher and Asconi Building Corp. v. Vocisano as meaning "by the terms of the mortgage itself". Consequently, it is arguable that if a mortgage is given as collateral security for the payment of a promissory note and provides expressly that the principal and interest will be repaid "in accordance with the terms of the promissory note," section 6 of the Interest Act will have no application at all because the principal and interest is made payable not by the mortgage, but by the collateral promissory note. This assumption underlies the form of collateral mortgage used by one chartered bank. Quaere as to the effect of a clause in the mortgage annexing the promissory note to, and making it a part of, the mortgage.

\section{(g.) Variable Rate Mortgages}

If interest is calculated monthly at a floating rate and the mortgage falls within one of the section 6 categories, it is essential that the mortgage contain a statement of the yearly or half-yearly interest rate. ${ }^{62}$ The variable rate mortgage form used by one chartered bank contains a comprehensive schedule of equivalent half-yearly rates. In the absence of such a schedule, a variable rate mortgage should be made payable on demand so as to remove it from section 6 altogether.

\section{(h.) Participation Mortgages}

It has been decided recently that a participation clause in a mortgage, which requires the payment of a percentage of gross annual rentals to the mortgagee, does not contravene section 6 of the Interest Act. Re Balaji Apartments Ltd. ${ }^{63}$ held that the payments were not interest, but a separate collateral aspect of the transaction. ${ }^{64}$ Quaere as to whether a participation clause might be subject to the Unconscionable Transactions Act. ${ }^{65}$

\section{Section 8 of the Interest Act}

The common provision in a mortgage providing that on default the mortgagor shall pay, in addition to the monies in default, a bonus equal to three months' interest in advance on the principal secured, is invalid

\author{
62. Supran. 56. \\ 63. (1980) 25 O.R. (2d) 275 (Ont. H.C.J.). \\ 64. See also North American Lifev. Beckhuson [1981] 2 W.W.R. 446 (Alta. Q.B.). \\ 65. See Western Capital Trust Co. v. R.W.C. Shelter(1982) A.W.L.D. 1007 (Alta. Q.B.).
}


under section 8 of the Interest Act, which prohibits any fine, penalty or rate of interest that has the effect of increasing the charge on any arrears of principal or interest beyond the rate of interest payable on principal money not in arrears. ${ }^{66}$ Further, in Les Immeubles Fournier Inc. v. Construction St. Hilaire, ${ }^{67}$ the Supreme Court of Canada held that a provision calling for payment of a fifteen percent indemnity on the institution by the mortgagee of legal proceedings of fends section $8 .{ }^{68} \mathrm{It}$ is important to note that section 8 was enacted in 1880 . Consequently, earlier decisions upholding an increased rate of interest after default were superceded by this legislation, viz. Waddell v. McColl ${ }^{69}$ and Downey v. Parnell. ${ }^{70}$

Section 8 does not prevent the parties from entering into a new mortgage, whereby the mortgagor agrees to pay interest at an increased rate in consideration of the forbearance by the mortgagor to commence proceedings under the defaulted mortgage. ${ }^{71}$ As well, a collateral verbal agreement to pay an increased rate of interest in consideration of an extension of time to pay is enforceable as a collateral contract. Because such contract does not charge the land, it does not of fend the Statute of Frauds and is outside the scope of section $8 .{ }^{72}$

It is arguable that a clause in a mortgage providing that the mortgagor shall not require the mortgagee to accept payment of the principal monies without first giving three months' previous notice in writing, or paying a bonus equal to three months' interest in advance, is enforceable notwithstanding section 8 because such clause applies only when the mortgagor requires the mortgagee to accept payment after default, as in the case of redemption, and does not apply where the mortgagee, himself, demands payment and sues for the increased interest. ${ }^{73}$ Quaere as to whether such a clause would be unenforceable in equity as a penalty..$^{74}$

As mentioned above, an allowance of interest on stipulated repayments may altogether run afoul of section $8 .{ }^{75}$

66. Schwartz v. Williams(1915) 35 O.L.R. 33 (Ont. S.C.); Levyv. Booksban (1931) 40 O.W.N. 187, 2 D.L.R. 1007 (Ont. S.C.); Tapio v. Kajander (1965) 48 D.L.R. (2d) 302 (Ont. Dist. Ct.); Re Belyon Properties Lid. [1968] 2 O.R. 257 (Ont. C.A.); Glinert v. Kosztowniak [1972] 2 O.R. 284 (Ont. S.C.); Parkhillv. Moher(1977) 3 R.P.R. 26 (Ont. H.C.J.); see also Tomell Investments v. East Martok Lands (1977) 2 R.P.R. 69 (Ont. S.C.), which also held s. 8 to be constitutionally valid.

67. (1974) 52 D.L.R. (3d) 89 (S.C.C.).

68. See also Coupland Acceptance v. Walsh (1954) S.C.R. 90; Bonan v. Millwick Finance (1978) 6 W.W.R. 577 (B.C.S.C.); Felix Senecal Inc. v. Mont Bon Plaisir Inc. (1979) 9 R.P.R. 238 (Que. S.C.).

69. (1868) $14 \mathrm{Gr} .211$ (Ont. Ch.).

70. [1882] 2 O.R. 82 (Ont. S.C.). The following cases also are now overshadowed by s. 8: $R e$ Houston [1882] 2 O.R. 84 (Ont. S.C.); Totten v. Watson (1870) 17 Gr. 233 (Ont. Ch.); Jackson v. Richardson 34 N.B.R. 301 ; affg. 1 N.B. Eq. 325 (N.B.C.A.).

71. Standard Trust v. Hurst (1914) 6 W.W.R. 493 (Man. C.A.).

72. Id.; Robert Porter \& Sons Ltd. v. MacKenzie (1926) 37 B.C.R. 287 (B.C.S.C.); Brown v. Deacon (1866) 12 Gr. 198 (Ont. C.A.); Keays v. Emard(1885) 10 O.R. 314 (Ont. Ch. Div.).

73. See Warrenv. Cairns(1915) 9 O.W.N. 232 (Ont. S.C.); Parkhillv. Moher, supra n. 66.

74. Supra n. 58. See also Standard Mtge. Co. v. Naayer(1978) 5 W.W.R. 385 (Man. Q.B.).

75. Supran. 57. 
The question has also been considered whether a mortgage which does not provide for the payment of any interest on principal not in arrears may provide for the payment of interest after maturity. In Macdonald $\mathrm{v}$. Muncey, ${ }^{76}$ a recent Alberta Queen's Bench decision, Master Hyndman held that such a provision did not offend section 8 . However, the converse was held in Pemberton Realty Corp. v. Carter, 77 while the Manitoba Queen's Bench has held that section 8 precludes the recovery of interest as damages, where no interest is chargeable on principal moneys not in arrears. ${ }^{78}$ Quaere as to whether section 8 applies if all principal monies are in default, that is to say, after maturity.79

3. Section 9 of the Interest Act

A mortgagor is entitled, by section 9 , to recover interest payments made contrary to sections 6,7 or 8 . If the monthly payment of principal and interest provided for by a mortgage is inconsistent with the stated rate and agreed amortization period, so as to result in a higher yield to the mortgagee, Credit Foncier v. Fort Massey Realties Ltd. states that the mortgagor may recover the excessive interest paid. ${ }^{80}$

\section{Section 10 of the Interest Act}

Section 10 of the Interest Act stipulates that in the case of mortgages given by natural persons, as opposed to corporations, for a term longer than five years, no further interest is recoverable upon the mortgage if the mortgagor (or other party entitled to redeem) tenders or pays to the mortgagee the amount due for principal, plus interest to the time of payment, plus a further three months' interest in lieu of notice.

Section 10 does not entitle the mortgagor to insist on a discharge; it only stops interest from running. ${ }^{81}$ Neither does the section contemplate the giving of notice only in lieu of payment of three months' interest, according to both Payment v. Prudential Insurance ${ }^{82}$ and Hone v. London Life. ${ }^{83}$

In $R e$ Hodgson, ${ }^{84}$ it was decided that an extension agreement by which a mortgage term is "renewed" is, as such, beyond the ambit of section 10. Renewal of a five-year mortgage for a further five years did not, in that case, create a ten-year term for the purposes of section 10 . The section was construed strictly as applying to a "mortgage", but not to an "extension agreement". ${ }^{85}$

76. (1980) 13 R.P.R. 199 (Alta. Q.B.).

77. (1975) 58 D.L.R. (3d) 478 (B.C.S.C.). See also Re Brown, supra n. 55.

78. Kwiatkowskiv. Capka [1977] 6 W.W.R. 572 (Man. Q.B.).

79. See Adams Properties Lid. v. Sherwood Estates Lid. (1975) 60 D.L.R. (3d) 190; revd. 1976 (unreported).

80. (1981) 46 N.S.R. (2d) 383 (N.S.S.C.).

81. Baxter v. Dercasz (1925) 3 W.W.R. 593 (Sask. C.A.); Re Moore (1965) 50 D.L.R. (2d) 300 (Ont. H.C.J.).

82. (1959) 28 W.W.R. 197 (Alta. Dist. Ct.).

83. (1981) 122 D.L.R. (3d) 315 (Ont. H.C.J.).

84. (1974) 47 D.L.R. (3d) 518 (Ont. H.C.J.).

85. Compare with Deethv. Standard Trust Co. (1980) 12 R.P.R. 157 (Ont. Div. Ct.). 
Quaere as to whether section 8 of the Interest Act prevents a mortgagee from stipulating for a bonus of interest if the mortgagor wishes to prepay the mortgage before maturity. ${ }^{86}$ However, according to Heritage Savings $\&$ Trust Co. v. Harke, ${ }^{87}$ the mortgagor can avoid the payment of any such bonus simply by allowing the mortgage to fall into arrears and then tendering the principal, interest and costs (absent bonus) when the mortgagee forecloses.

Although section 10 has the practical effect of forcing a mortgagee to accept prepayment of the mortgage, a mortgagee is not otherwise bound to accept prepayment of his mortgage before the maturity date. ${ }^{88}$ On the other hand, expropriation of the mortgaged lands has been held to frustrate the mortgage security and to compel the mortgagee to accept prepayment. ${ }^{89}$

\section{E. COMPOUND INTEREST}

1. Interest in Default

\section{(a.) General}

Interest will not be payable on interest in default, whereby interest is converted into capital, unless the mortgage so provides in clear, unambiguous language..$^{90}$

The method of calculating interest on arrears of interest was considered in Canada Permanent Loan v. Hilliard. ${ }^{91}$ In that case, it was held that if six months' interest is due and unpaid, the mortgage stands as security for the principal money then due plus six months' interest, and that the aggregate of the then principal plus six months' interest bears interest at the same rate as provided in the mortgage. If default is made again in another six months' time, the amount of interest then added to principal is six months' interest on the aggregate of the original principal and the six months' interest which became principal when the first installment of interest was not paid six months before. According to Elman v. Conto, ${ }^{92}$ it is unnecessary to make express provision in the mortgage for rests.

86. See Standard Mtge. Co. v. Naayer, supra n. 74.

87. (1978) 13 R.P.R. 11 (Alta. C.A.).

88. Re Hodgson, supra n. 84.

89. $\operatorname{Re}$ Canton-Lawson (1958) O.W.N. 217 (Ont. H.C.).

90. See Imperial Trusts Co. v. New York Security (1905) 10 O.L.R. 289 (Div. Ct.); Sask. Land v. Leadlay (1910) 16 O.W.R. 890; affg. 14 O.W.R. 1096 (C.A.); Eastern Trust v. Berube (1914) 7 O.W.N. 114 (T.D.); Trusts Corp. of Ontario v. Hood (1896) 23 O.A.R. 589 (C.A.); Manitoba and North Western Loan v. Barker(1892) 8 Man. R. 296 (T.D.); King v. Keith (1898) 1 N.B. Eq. 438; 555; Wilson v. Campbell (1879) 8 P.R. 154 (Ch.D.); Thompson v. O'Toole (1888) 21 N.S.R. I (N.S.S.C.); Jackson v. Richardson, supra n. 70; Belgrand v. Northern Heights (1971) 18 D.L.R. (3d) 399 (Ont. H.C.); Montreal Trust v. Hounslow (1971) 22 D.L.R. (3d) 503 (Ont. H.C.); North West Trust Co. v. Orion Properties Ltd. (1981) 10 Sask. R. 134 (Q.B.).

91. (1885) 3 Man. R. 32 (T.D.).

92. (1978) 82 D.L.R. (3d) 743 (Ont. C.A.). 


\section{(b.) Assignment of Mortgage}

The assignee of the mortgagee's interest under a land mortgage who pays interest in arrears to the assignor is not, without the consent of the mortgagor, entitled to treat such interest as principal so as to bear compound interest. ${ }^{93}$

\section{(c.) Redemption by Subsequent Encumbrancer}

In McMaster v. Hector, ${ }^{94}$ it was held that a subsequent encumbrancer who redeems a prior mortgage is entitled to interest on the interest paid by him to the prior mortgagee at the statutory rate only.

(d.) Compound Interest Prior to Default

\section{(i) General}

The mathematical formula applied to determine compound interest is: $S=P(1+i)$. " $P$ " is the original principal, " $S$ " is the compound amount (i.e. the principal at the end of the "nth" period); the number of conversion (compounding) periods is " $n$ " and " $i$ " is the interest rate per conversion period. By way of illustration, if a $\$ 1,000.00$ mortgage calls for interest at twelve per cent per annum compounded (calculated) monthly not in advance, the compound amount at the end of twelve months is: $\$ 1,000.00 \times(1+.12 / 12)^{12}=\$ 1,126.82$. It follows that the effective annual (i.e. simple) interest rate is 12.68 per cent (ef fective rate $=$ compound interest for one year/principal).

The mathematical formula applied to determine equivalent interest rates is: $1+i=(1+j / m)^{m}=(1+J / M)^{M}$. In this formula, " $i$ " is the annual rate compounded annually, " $\mathrm{j}$ " is the nominal annual rate compounded " $\mathrm{m}$ " times per annum, and " $\mathrm{J}$ " is the nominal annual rate compounded " $M$ " times per annum.

It is implicit in the mathematical concept of compound interest that interest earned is automatically reinvested so as to "write-up", i.e. increase, the principal. However, when interest is paid more frequently than the compounding period, it is another mathematical concept that the interest actually received by the lender is deemed to have been reinvested by him at the contractual rate. On the assumption that the lender is entitled to an effective interest at the contractual rate only, the deemed reinvestment earnings are applied to "write-down", i.e. reduce, the interest payable by the borrower. Mortgage amortization tables commonly in use contain "blended" monthly payment factors and interest factors based on the deemed reinvestment principle.

A mortgage may call for the payment of interest prior to default in one of three ways:

(a) Interest payable coterminously with the compounding period, viz. the payment interval and the compounding interval are the same. For example, interest at the rate of twelve per cent per annum compounded (calculated) monthly not in advance and payable monthly. (The deemed reinvestment principle referred to above does not apply to

93. Thomas v. Girvan (1896) I N.B. Eq. 257 (T.D.).

94. (1872) 8 Can. L.J. 284. 
"write-down" the interest because interest is payable at the same time it is calculated.)

(b) Interest payable more frequently than the compounding period. For example, interest at twelve per cent per annum compounded (calculated) semi-annually not in advance and payable monthly. (In this case the deemed reinvestment principle may and, arguably, should apply to "write-down" the interest because the mortgagee is receiving a monthly prepayment of his interest and his actual yield should not be more than twelve per cent compounded semi-annually. If the principal sum is being reduced by "blended" monthly installments, there is a "write-down" of capital each month as well. In this example interest is converted into capital before default.)

(c) Interest payable less frequently than the compounding period. For example, interest at twelve per cent per annum compounded (calculated) monthly not in advance and payable annually. (In such case the deemed reinvestment principle would not apply to "writedown" the interest because there is no prepayment of interest.)

(ii) Calculation of Interest When Payable More Frequently than Compounding Period; Deemed Reinvestment

The interpretation of such compound interest clauses has led to considerable misunderstanding. The concepts are essentially mathematical. As noted by $\mathrm{H}$. Woodard in Canadian Mortgages: ${ }^{95}$

[t]he words "compounded", "calculated", "computed" . . . are considered to be synonymous terms. . . . None of them has any necessary relationship to the time at which interest is payable. . . . The qualifying wording is used solely to express, in explicit terms, the frequency of the compounding of the interest. The more frequent the "calculation" or "compounding", the higher is the effective yield to the lender. Thus " $6 \%$ calculated monthly" produces a higher ef fective rate than " $6 \%$ calculated semiannually. . . . When interest is payable by the borrower more frequently than once each period of compounding as expressed in the contractual interest rate, all interest mathematics are based on the theory that the lender reinvests the interest received from time to time, at the same rate. Therefore, the amounts of interest received from the borrower, plus theoretical re-investment earnings on them, produce, for the lender, the effective yield contemplated in the borrowing instrument. . . .

These excerpts from Woodard were approved by the Ontario Divisional Court in Re Tilson. ${ }^{36}$ In that case, the Court applied the "reinvestment principle" to a mortgage which provided for payments of interest and principal more frequently than the compounding periods. In most conventional mortgages, interest is compounded half-yearly but payable monthly. Therefore, it is necessary to consider the appropriate method of calculating the mortgage balance in such case. The familiar practice of determining the interest for a six-month period on the outstanding principal, and adding to that amount the principal sum, and then deducting from that sum the blended payments made over the six month period, was held to be an improper method of calculation of the mortgage balance in Re Miglinn and Castleholm Construction. ${ }^{97}$ In that case, the Ontario Court of Appeal decided that the proper method of calculation is

95. Unfortunately, this text is now out of print.

96. (1975) 57 D.L.R. (3d) 491 .

97. (1975) 50 D.L.R. (3d) 524 . 
for the mortgagee to apply the appropriate mathematical formula to "write-down" the interest and to use the capital component of each monthly payment immediately to "write-down" the balance of the capital outstanding each month.

The reinvestment principle also was applied in the case of Re Fobasco Ltd. ${ }^{98}$ In that case, the mortgage provided for payment of monthly instalments of interest only. The Court of Appeal held that the reinvestment principle applied irrespective of the fact that principal was not payable by monthly instalments. ${ }^{99}$ However, in the more recent case of Metro Trust v. Morenish Land Developments Ltd., 100 the Supreme Court of Canada considered facts on all fours with those in $R e$ Fobasco, and held that the reinvestment principle does not apply generally, and that it did not apply to the particular mortgage in that case. Re Fobasco has, accordingly, been overruled.

It is interesting to note that the Supreme Court in the Metro Trust case distinguished the Tilson and Miglinn cases on the ground that they dealt with blended payment mortgages. Yet, in both the Tilson and the Miglinn cases the mortgage contained a "Kilgoran Hotels clause." "101 Although in Tilson and Miglinn the payment and compounding dates were different, whereas they were the same in Kilgoran, this does not appear to be a suitable basis for characterizing the payments in Tilson and Miglinn as "blended".

\section{E. LIMITATION OF ACTIONS}

By section 15 of the Limitation of Actions Act, ${ }^{102}$ no arrears of interest in respect of a sum of money charged on or payable out of land may be recovered except within six years next after a present right to recover the interest accrued to a person capable of giving a discharge therefor or a release thereof. By virtue of s.15(3), this limitation does not apply to an action for redemption brought by a mortgagor. ${ }^{103}$ Neither does the limitation apply to a foreclosure action, which, by section 34 of the Limitation Act, may be brought within ten years after the right to do so first accrued to the mortgagee. ${ }^{104}$

\section{AGREEMENTS OF SALE}

\section{A. CONTRACTUAL OBLIGATION TO PAY INTEREST \\ 1. General Principles}

In the absence of an agreement to the contrary, a purchaser will not be required to pay interest on the unpaid purchase price before going into possession. ${ }^{105}$ However, the parties may agree that the purchaser will pay

98. [1976] 13 O.R. (2d) 342.

99. See also Sparhaven Farms v. Brampton West (1980) 14 R.P.R. 289 (Ont. S.C.).

100. (1981) 19 R.P.R. 281.

101. See Re Kilgoran Hotels Lid., supra n. 48.

102. R.S.A. 1980, c. L-15.

103. See Great West Acceptance Corp. Ltd. v. Hamilton Hotel [1982] 3 W.W.R. 577 (Sask. C.A.).

104. Cf. Great West Acceptance Corp. Ltd. v. Wascana Hotel [1981] 3 W.W.R. 747 (affd. 1982 by the Sask. C.A.).

105. Parkerv. Kogos(1925) S.C.R. 513. 
interest before taking possession. Only if the vendor is in default or is guilty of misconduct, will he be disallowed his interest where a purchaser not in possession has agreed to pay interest before taking possession. If the purchaser is in possession, he may avoid the payment of interest only if the vendor is in wilful default, provided that the purchaser has deposited the purchase monies in a separate account. In addition, a clause in a contract requiring the purchaser to pay interest if payment of the purchase money is delayed "from any cause whatever" will not exonerate a vendor from his wilful default. ${ }^{106}$

As decided in Moraw v. Maginnis, ${ }^{107}$ an obligation to pay interest after the purchaser takes possession may also be an implied term of the contract. ${ }^{108}$

The granting of an option to purchase to a third party by a purchaser not in actual possession does not constitute constructive possession so as to start interest running. ${ }^{109}$

As a general rule, moneys paid under an agreement for sale must be applied firstly on interest and then on principal. ${ }^{110} \mathrm{~A}$ number of cases have laid down principles to deal with the construction of particular interest clauses. ${ }^{111}$

\section{Interest Act}

If the agreement does not specify the rate of interest payable, the statutory rate of five per cent will be implied under section 3 of the Interest Act. As well, it should be noted that, by section 4 of the Interest Act, if interest is payable other than at a per annum rate (i.e. per day, per month or "per" another period less than one year), interest at five per cent per annum only shall be recoverable by the vendor if the agreement does not state the equivalent yearly rate. ${ }^{112}$

Section 4 applies to all written contracts, except mortgages of real estate. Sections 6 to 10 of the Interest Act apply only to mortgages of real estate.

\section{Trust Conditions}

It is submitted that if the parties have expressly agreed on a rate of interest to apply if payment of the purchase price is delayed after the closing date, the solicitor for the vendor may not properly exact a higher rate

106. Re Dingman and Hall's Contract (1890) 17 O.A.R. 398; Hayes v. Elmsley (1893) 23 S.C.R. 623; Stevenson v. Davis (1893) 23 S.C.R. 629; Quinlan v. O'Connell(1911) 16 W.L.R. 288 (Sask. T.D.); Rogers v. Leonard (1974) 39 D.L.R. (3d) 349 (Ont. H.C.).

107. [1929] W.W.R. 68 (Alta. S.C.T.D.).

108. (1855) 5 Gr. 192 (Ch.).

109. Fred Morton Holdings v. Davis [1979] W.W.R. 549 (S.C.C.).

110. See McGregorv. Gaulin (1848) 4 U.C.Q.B. 378; Bettes v. Farewell (1865) 15 U.C.C.P. 450; Wilson v. Rykert (1886) 14 O.R. 188; Deacon v. Webb (1903) 2 O.W.R. 110 (Div. Ct.); Jones v. Spencer(1920) 18 O.W.N. 130 (Ont. S.C.).

111. See Gould v. Thompson [1924] W.W.R. 191 (B.C.C.A.); Rink v. March [1921] 1 W.W.R. 919 (Sask. S.C.T.D.); Parker v. Trustee Co. of Winnipeg [1918] 2 W.W.R. 264 (Man. K.B.T.D.); Great West Lumber Co. v. Wilkins (1907) 7 W.L.R. 166 (Alta. Trial); D'Hart v. McDermaid (1910) 44 N.S.R. 546 (S.C.).

112. See Barbour v. Paradis (1929) 68 Que. S.C. 31; Re Keating [1937] O.W.N. 214 (C.A.). 
in his trust conditions. Quaere as to whether such trust conditions, in the absence of an express provision in the agreement of sale, effect a variation of the contract to provide for postponement of the time for payment until a date later than the closing date, such variation arising upon acceptance of the trusts by the solicitor for the purchaser.

\section{Compound Interest}

Eggan v. Griffiths establishes that as in the case of mortgages, if compound interest is to be recoverable under an agreement of sale, the agreement must clearly so provide. ${ }^{113}$ In the absence of the agreement otherwise providing, Shoyle Holdings Ltd. v. Hunter holds that interest under an agreement for sale is to be calculated annually and not in advance. ${ }^{114}$

\section{B. INTEREST AS DAMAGES}

In the absence of an express agreement to pay interest, interest may be recovered from a defaulting purchaser under section 15 of the Judicature Act, the unpaid price being a just debt improperly withheld. ${ }^{115}$

\section{INTEREST AS EQUITABLE COMPENSATION}

In the absence of an express agreement to pay interest or an agreement to the contrary, a purchaser who goes into possession must pay interest on the unpaid price from the date of taking possession because it would be inequitable for him to have the benefit of possession and also of the purchase money. ${ }^{116}$ However, Hart v. Maine ${ }^{117}$ states that this principle applies only if the contract is executory. Furthermore, the principle does not apply if the purchaser has expressly agreed to pay rent. ${ }^{118}$

Quaere as to whether an unpaid vendor is entitled to recover occupation rent from a defaulting purchaser in possession: while Tavender $\mathrm{v}$. Edwards ${ }^{119}$ states that he may, Laczco v. Patterson ${ }^{120}$ takes the opposite viewpoint.

A claim for occupation rent may be made by the vendor if the purchaser continues in possession after lawfully repudiating the contract. ${ }^{121}$ A vendor who retains possession may not recover interest if he claims damage on the ground of the purchaser's default instead of claiming

113. [1949] 2 D.L.R. 669 (Ont. C.A.).

114. (1980) 19 B.C.L.R. 359 (B.C.S.C.).

115. See Walker v. Card (1915) 7 W.W.R. 1145 (Alta. S.C.T.D.); Kennedy v. Inman [1920] 3 W.W.R. 564 (Alta. S.C. App. Div.) (where there was no agreement to pay interest on principal after maturity).

116. See Great Western Ry. v. Jones (1867) 13 Gr. 355 (Ch.); Bank of Montrealv. Fox (1875) 6 P.R. 217 (Chan. Chambers); Vanzant v. Burke (1876) 38 U.C.Q.B. 104; Anderson v. Phinney (1905) 38 N.S.R. 393 (S.C.); Toronto v. Toronto Ry. [1926] 3 D.L.R. 629 (Ont. S.C.); International Ry. v. Niagara Parks Commn. [1941] 2 W.W.R. 338 (J.C.P.C.); Laczko v. Patterson (1972) 22 D.L.R. (3d) 288 (Ont. C.A.).

117. [1929] 2 W.W.R. 661 (J.C.P.C.).

118. Westridge Developments v. Can-Am Development (1978) 14 A.R. 318 (S.C.T.D.).

119. (1908) Alta. L.R. 333 (S.C.).

120. Supran. 116.

121. Walters v. Capron (1965) 50 W.W.R. 444 (B.C.S.C.); Rowley v. Isley (1951) 3 W.W.R. (N.S.) 173 (B.C.S.C.). 
specific performance, in which latter instance the purchaser might be charged with interest and the vendor with an occupation rent after the proper time for completion. ${ }^{122}$

\section{VENDOR'S OBLIGATION TO PAY INTEREST}

A purchaser who is entitled to rescind an agreement of sale is entitled to an equitable lien on the land for all sums paid under the agreement. As the lien does not extend to damages, because it is a remedy involving disaffirmation of the contract, it may not extend to interest (as damages) on the amount paid by the purchaser. ${ }^{123}$

Finally, section 15 of the Judicature Act will also avail a purchaser who has lawfully repudiated his agreement and seeks interest on purchase monies wrongfully withheld by the vendor. ${ }^{124}$

122. Goldenberg v. Lieberman (1951) 2 D.L.R. 584 (Ont. H.C.).

123. See Whitbread v. Watt [1902] Ch. 835 (C.A.); Dayv. Singleton [1899] 2 Ch. 320 (C.A.).

124. Bellv. Krohn [1931] 2 W.W.R. 701 (Sask. C.A.).

125. Canada Law Book, 1977.

126. Carswell, 1976.

127. Richard De Boo, 1979.

128. L.S.U.C., 1976.

129. Carswell, 1915. 